\title{
EVALUATION OF THE DENTAL EFFECTS OF LARYNGOPHARYNGEAL REFLUX
}

by

\author{
John A Chamberlain III, DMD \\ LT, DC, USN
}

A thesis submitted to the Faculty of the

Prosthodontic Graduate Program

Naval Postgraduate Dental School

Uniformed Services University of the Health Sciences

in partial fulfillment of the requirements for the degree of

Master of Science

in Oral Biology

March 2015 
Naval Postgraduate Dental School

Uniformed Services University of the Health Sciences

Bethesda, Maryland

CERTIFICATE OF APPROVAL

MASTER'S THESIS

This is to certify that the Master's thesis of

John A Chamberlain III, DMD

Lieutenant, Dental Corps, U.S. Navy

has been approved by the Examining Committee for the thesis requirement for the Master of Science degree in Oral Biology at the June 2013 graduation.

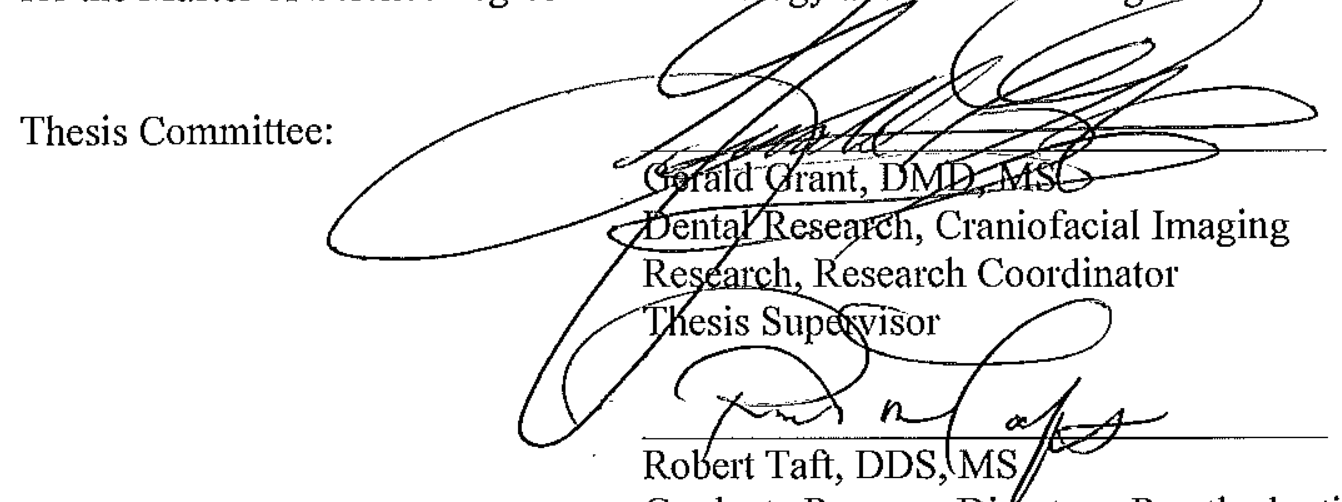

Graduate Program Director - Prosthodontics

Chairman

Anton Petrich, DDS, MS

Research Mentor

Prosthodbhtics Ghief, Complete Dentures
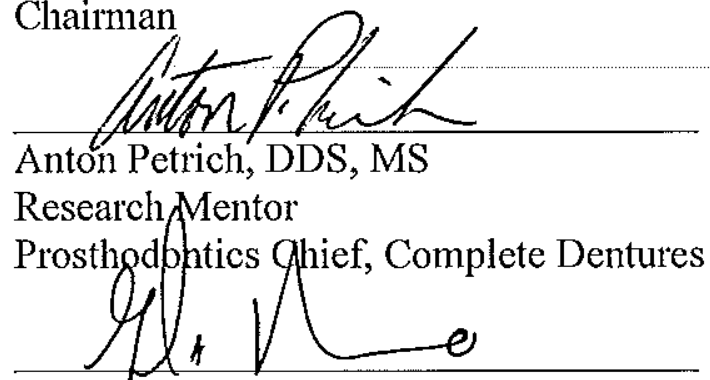

GlemA. Munro, DDS, MBA

Dean

Naval Postgraduate Dental School 
The author hereby certifies that the use of any copyrighted material in the thesis manuscript titled:

\section{EVALUATION OF THE DENTAL EFFECTS OF LARYNGOPHARYNGEAL REFLUX}

is appropriately acknowledged and, beyond brief excerpts, is with the permission of the copyright owner.

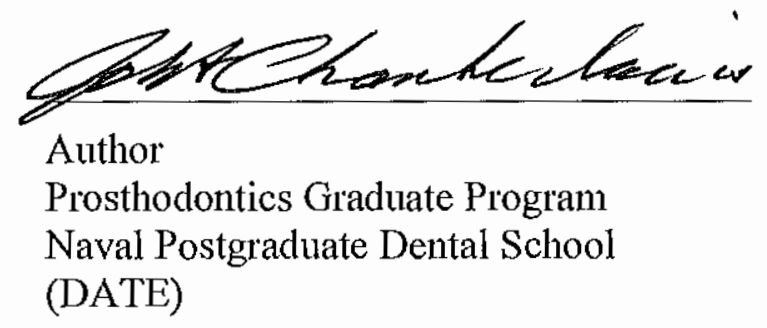

\section{NAVAL POSTGRADUATE DENTAL SCHOOL John A Chamberlain III, DMD}

2015

This thesis may not be re-printed without the expressed written permission of the author. 


\begin{abstract}
The association between dental erosion and gastroesophageal reflux (GERD) is well known and documented in the literature. Laryngopharyngeal reflux (LPR) is a lesser known clinical disorder that can mimic this destruction of hard tissues in the oral cavity. Although these processes are related, each features differences in symptomology, clinical findings, pathophysiology and treatment options. Because LPR typically does not present with classic GERD symptoms such as heartburn or acid reflux, patients typically do not seek treatment for the condition which would lead to a diagnosis. Like GERD, LPR also presents with a number of potential medical complications, the most severe being laryngeal carcinoma. LPR is referred to as silent reflux in the literature but because of its association with cancer in the upper airway spaces, it is considered a silent killer.
\end{abstract}




\section{TABLE OF CONTENTS}

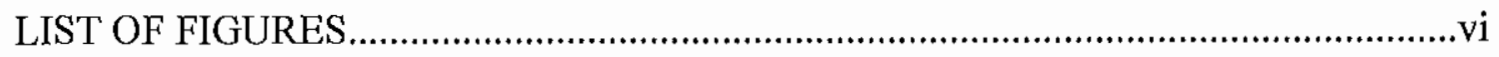

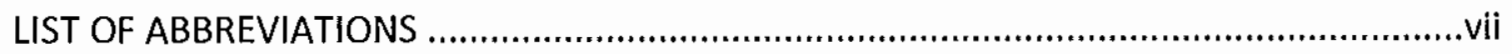

CHAPTER

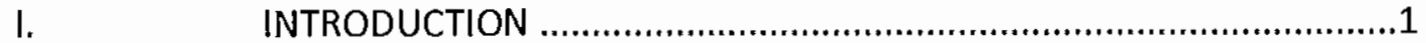

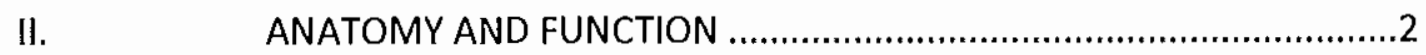

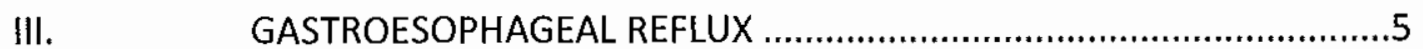

IV. LARYNGOPHARYNGEAL REFLUX ............................................10

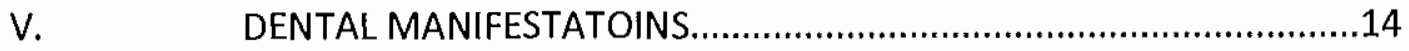

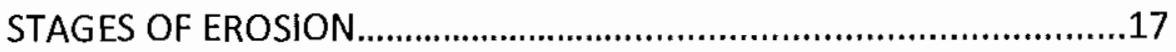

OTHER DENTAL FINDINGS..........................................................

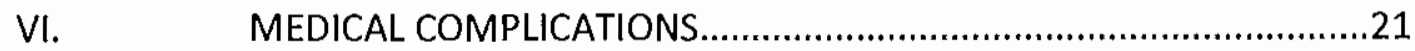

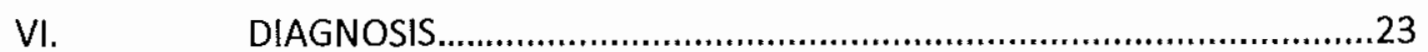

VI. TREATMENT

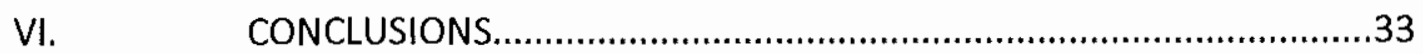

REFERENCES 
- All figures created by the thesis author with the exception of figure 6, courtesy of Janet C. Shaw MD, Department of Gl/Hepatic Pathology, Joint Pathology Center. 


\section{LIST OF ABBREVIATIONS}

\begin{tabular}{|c|c|}
\hline GER & Gastroesophageal Reflux \\
\hline GERD & Gastroesophageal Reflux Disease \\
\hline hCG ............... & Human Chorionic Gonadotropin \\
\hline LES & Lower Esophageal Sphincter \\
\hline LPR & Laryngopharyngeal Reflux \\
\hline PPI & Proton Pump Inhibitor \\
\hline . & Squamous Cell Carcinoma \\
\hline JES & Upper Esophageal Sphincter \\
\hline
\end{tabular}




\section{INTRODUCTION}

Most clinicians are familiar with the process of dental erosion and the resulting destruction of hard tissues within the oral cavity. This phenomenon has been attributed to a number of possible causes but is ultimately the result of intrinsic or extrinsic acids which dissolve the hard tooth surfaces over time. One of the leading causes of erosion in some patients can be attributed to gastroesophageal reflux disease (GERD), a clinical disorder which is caused by chronic esophageal acid exposure. A related but lesserknown condition is laryngopharyngeal reflux (LPR), which is also known as extraesophageal reflux disease, extra-esophageal GERD, silent erosive esophagitis, silent GERD or silent reflux in the literature. Although these processes share certain similarities, the etiology is different which results in different clinical presentations. LPR is similar to GERD in that it allows endogenous stomach acids to enter the upper airways, but does usually not present with the usual symptoms which would cause a patient to seek treatment. As such it can go undiagnosed and result in a variety of dental and medical complications. Of particular concern are the potential associations with Barrett esophagus and laryngeal carcinoma. 


\section{ANATOMY AND FUNCTION}

As a review, the esophagus is a $25 \mathrm{~cm}$ hollow fibromuscular tube that allows the passage of foods and liquids from the pharynx to the stomach. Each end is bound by a muscular ring, or sphincter, which serve to mitigate the backflow of gastric contents into the esophagus, pharynx and upper airways. The upper end of the esophagus is bound by the upper esophageal sphincter (UES) which measures $2-4 \mathrm{~cm}$ in length. This sphincter is composed of striated or skeletal muscle but is not under conscious control; instead it is triggered by the swallowing reflex. The primary function of the UES is to protect the upper airway spaces from retrograde movement of stomach contents (Wilson \& Heading, 1993, pp. 357-372).

The lower end of the esophagus is bound by the lower esophageal sphincter (LES) which measures $2.5-3.5 \mathrm{~cm}$ in length. Unlike the UES, the LES is composed of smooth muscle and involves muscles of both the diaphragm and folds of the stomach. The LES is not a true anatomical sphincter but is a physiological sphincter that is under involuntary control by the sympathetic trunk and the vagas nerve. The primary function of the LES is to minimize movement of stomach contents back into the esophagus but, due to variable basal pressure, backflow of gastric contents commonly occurs after meals. This is typically cleared by swallowing and peristalsis within the esophagus (Johnson \& DeMeester, 1974). It is important to note that the esophagus is lined with squamous epithelium but there is an abrupt change at the gastro-esophageal junction, to simple columnar epithelial cells with gastric glands and pits (Meyer, Austin, Brady, \& 
Castell, 1986). This squamo-columnar junction is of particular importance in patients with acid reflux disease as it is ground zero for the development of Barrett esophagus, a pre-malignant condition that is associated with esophageal adenocarcinoma (Naini, Chak, Ali, \& Odze, 2014).

As a system, the esophagus has several functions. The first is to allow the passage for solids and liquids from the pharynx to the stomach in a synchronized manner. The second function is clearance; in the event of blockage or regurgitation, muscular peristalsis moves this material from the esophagus and into the stomach. The third function is the prevention of gastroesophageal reflux due to the esophageal sphincters which work as physical barriers to the retrograde movement of stomach contents to the esophagus and upper airway spaces (Bartlett D. , 2006). During deglutition or swallowing, food or liquids pass from the mouth, to the pharynx and into the esophagus, while shunting the epiglottis. This occurs in three phases, the first of which is the oral phase which involves the intake, chewing and lubrication of food. This is a voluntary process and involves the muscles of facial expression, muscles of mastication, musculature of the tongue, and parasympathetic innervation to the salivary glands which are supplied via cranial nerves V3, VII, IX and XII. The second stage is the pharyngeal phase and is an involuntary reflex. This begins with the closure of the nasopharynx by the tensor palatini and levator palatini, and approximation of the pharyngeal walls by cranial nerves V3, IX and X. Next, the oropharynx is closed by the palatoglossus, intrinsic muscles of the tongue, and styloglossus via cranial nerves 9,10 \& 12. Finally, the larynx is closed by adduction of the vocal cords by cranial nerve $X$, which 
temporarily closes the epiglottis and prevents the aspiration of food. This is concluded with peristalsis via the pharyngeal constrictor muscles which forces the bolus through a relaxed upper esophageal sphincter and into the esophagus. The third and final phase is the esophageal phase and is also under involuntary neuromuscular control via the Vagas nerve (Buthpitiya, Stroud, \& Russell, 1987). This involves the process of peristalsis, the simultaneous mesial constriction and distal relaxation which drives the bolus towards the stomach at a rate of $2-5 \mathrm{~cm} / \mathrm{s}$ in healthy patients (Richter JE, Blackwell, Nelson III, Castell, \& Castell, 1987). This process is concluded by relaxation of the lower esophageal sphincter which allows the bolus to enter the stomach (Logemann, 2014). 


\section{GASTROESOPHAGEAL REFLUX}

Because the LES is not a true or tight anatomic sphincter, retrograde movement of the gastric contents into the distal esophagus can occur under certain conditions. This is called gastroesophageal reflux (GER) and is based on the Latin word refluere, which means to backflow (Koufman, 2002). This is considered a normal physiologic function and is due to transient relaxation of the lower esophageal sphincter which exhibits variable basal pressure based on muscular input via the Vagas nerve (Dent, et

al., 1980). Gastroesophageal reflux typically occurs postprandial, or after meals, for about an hour a day, but up to 50 GER episodes per day is considered within the normal range (Demeester, Johnson, Joseph, Toscano, Hall, \& Skinner, 1976; Postma, 2000). A GER episode is diagnosed when esophageal $\mathrm{pH}$ drops below 4.0 for at least 30 seconds. This $\mathrm{pH}$ is critical because cell death and mucosal injury occurs below this point (Orr, 2005).

Fortunately, there are a number of protective mechanisms which prevent mucosal injury in the majority of healthy patients. These include salivary production and bicarbonate buffering, esophageal peristalsis, and the squamous mucosal barrier (Orr, 2003; Pedersen, Bardow, Jensen, \& Nauntofte, 2002). Because the squamous epithelium in the esophagus lacks the protective lining as that found in the stomach, chronic acid reflux can result in mucosal damage and sensory nerve stimulation of the esophageal tissues. This is likely the result of direct contact with refluxed acid which liberates cytokines that stimulate epithelial sensory nerve endings (Chandrasoma, 
2010). The end result is usually symptoms of esophagitis including heartburn and acid regurgitation which are diagnostic for a clinical disorder called gastroesophageal reflux disease (GERD). Although GERD can exhibit extra-esophageal symptoms, the presence of heartburn and/ or acid regurgitation at least once a week for the last 3 months are considered essential in diagnosis of the condition (Choi, Jung, Song, Shim, \& Jung, 2013). Other typical symptoms may include a sour taste due to low $\mathrm{pH}$ levels of the stomach acids, as well as burping and/or belching. Patients may also report atypical symptoms which are largely extraesophageal due to mesial migration of endogenous stomach acids. These may include chest pain, sinusitis, globus, chronic cough, asthma-like symptoms, dysphagia, odoynophagia, water brash, coarse or hoarse voice, as well as nausea and/or vomiting (Rabine \& Nostrant, 2009; Fass, Achem, Harding, Mittal, \& Quigley, 2004; Heidelbaugh, Gill, Van Harrison, \& Nostrant, 2008).

GERD can occur at any time during the day but is typically exacerbated when in a supine position. In fact, it is estimated that up to $79 \%$ of patients exhibit nighttime GERD symptoms (Shaker, Castell, Schoenfeld, \& Spechler, 2003). Salivary flow follows a daily circadian rhythm but is greatest during waking hours, with an average of 25 to 60 swallows per hour. During sleep, the swallow reflex exhibits a fraction of that amount and may be as little as 2 to 9 times for the entire night (Thie, Kato, Bader, Montplaisir, \& Lavigne, 2002). Because salivary flow rate is reduced during sleep, esophageal clearance and salivary buffering are also diminished, allowing the proximal migration of gastric contents. As such, patients will often wake with typical, as well as extraesophageal, symptoms (Ranjitkar S, 2012). Furthermore, many GERD patients 
exhibit esophageal dysmotility and prolonged clearance rates which serve to exacerbate the condition (Postma, Tomek, Belafsky, \& Koufman, 2001).

As for the pathophysiology of GERD, there are a number of possible causes, but the most common reasons are insufficient function of the LES which allows stomach contents to enter the esophagus, and impaired motility which results in prolonged esophageal clearance of these substances (Koufman, 1991; Postma, Tomek, Belafsky, \& Koufman, 2001). These gastric contents may include liquid or gaseous acid vapors, as well as pepsin, a proteolytic enzyme produced by chief cells in the stomach that is responsible for initial protein catabolism (Rabine \& Nostrant, 2009; Dunn, 2002). Esophageal injury is likely the result of the synergistic effects of pepsin and the acid which activates it. In fact, studies have shown that esophageal damage is proportional to the amount of pepsin present and that acid at a $\mathrm{pH}$ of 2.3 was ineffective without the enzyme. (Goldberg, Dodds, Gee, Montgomery, \& Zboralske, 1969). At higher concentrations, hydrogen ions are highly corrosive and damaging to the apical surface of the squamous epithelium. The overall mechanism of damage is penetration of the epithelium by acids at low $\mathrm{pH}$, then proteolysis of type IV collagen by pepsin which disrupts the basement membrane of the squamous epithelial cells (Kresina \& Miller, 1979; Ingber \& Folkman, 1989; Bardhan, Strugala, \& Dettmar, 2012).

Epidemiology studies indicate that GERD shows increasing prevalence worldwide, especially in Western countries. In North America, the prevalence of symptomatic GERD is estimated at $18-28 \%$ of the population. In South America this 
estimate is $23 \%$, and in Europe it ranges from 9-26\%. In comparison, Asian countries show a much lower prevalence with $2.5 \%-8 \%$ in East Asia, and $9 \%-33 \%$ in the Middle East (El-Serag, 2007; El-Serag, Sweet, Winchester, \& Dent, 2014). In terms of cost of direct health care, GERD had the highest annual direct cost among digestive diseases in the late 1990s with an annual direct cost of $\$ 9.3$ billion dollars (Sandler, et al., 2002). By 2004 , this cost had escalated with an estimated direct cost of $\$ 12.1$ billion (Rubenstein $\&$ Chen, 2014). Although there are a number of theories that attempt to explain this increase, the literature is inconclusive. Changes in diet or lifestyle are often attributed to an increase in GERD but the level of evidence is low. In contrast, there is a definite relationship between GERD symptoms and obesity with associated increased body mass index, waist circumference and weight gain (Corley \& Kubo, 2006; Hampel, Abraham, \& El-Serag, 2005). This finding correlates to the number of Americans who are overweight or obese which has tripled over the last two decades (Mokdad, et al., 2001; Ogden, Carroll, Curtin, McDowell, Tabak, \& Flegal, 2006; Sturm, 2002).

There are a number of generally accepted risk factors for reflux, the first are conditions that result in incompetence of the lower esophageal sphincter. These can include alcohol, nicotine, caffeine, or hiatal hernia, the protrusion (or herniation) of the upper part of the stomach into the thorax through a tear or weakness in the diaphragm. In addition, certain medications such as calcium channel blockers or anticholinergic agents have been shown to cause LES incompetence (Allen M. , Mellow, Robinson, \& Orr, 1987). Second are conditions which increase gastric volume such as eating a large meal or intestinal blockage which result in slowed gastrointestinal motility. A common 
misconception is that the speed of eating results in greater risk of reflux has been shown to have no scientific basis (Valitova, Bayrakçı, \& Bor, 2013). Third include foods which act as potent refluxogenic agents such as raw onions or spicy meals, or meals that delay gastric emptying such as foods high in fats (Allen M. , Mellow, Robinson, \& Orr, The American Journal of Gastroenterology; Mushref \& Srinivasan, 2013). Fourth are conditions which increase intra-abdominal pressure such as obesity, pregnancy or straining during weight lifting (Dodds, Dent, \& Hogan, 1982). Finally, there are a number of other conditions that may have a role in the development of reflux and include sex, age, buffering capacity of the saliva, and infection of Helicobacter pylori (Sonnenberg \& El-Serag, 1999; Nozu \& Komiyama, 2008; Wang, Tu, Chuang, Yu, Cheng, \& Hsu, 2010; Cho, et al., 2011). 


\section{LARYNGOPHARYNGEAL REFLUX}

Laryngopharyngeal reflux (LPR) is similar to GERD but is a separate clinical disorder that goes by a number of names in the literature including extraesophageal reflux disease, non-acidic gastric reflux, extra-esophageal GERD, silent erosive esophagitis, silent GERD or silent reflux. Like GERD, LPR involves the reflux of endogenous stomach acids and into the esophagus through the normal physiologic process of gastroesophageal reflux through the lower esophageal sphincter. But unlike GERD, this typically extends into the upper airway spaces including the larynx, pharynx and oral cavity (Koufman, 2002). The result is a number of differences in symptomology, clinical findings, pathophysiology and treatment options. While heartburn and acid reflux are often considered the sine qua non of GERD, these symptoms, are often absent in patients with LPR. In fact, literature suggests that heartburn is present in $6-40 \%$ of patients with LPR (Koufman, Belafsky, Bach, Daniel, \& Postma, 2002 ; Ossakow, Elta, Colturi, Bogdasarian, \& Nostrant, 1987).

This difference is likely attributed to the fact that LPR patients typically exhibit reflux symptoms during the day, when salivary flow and esophageal clearance are at their peak (Belafsky \& Postma, 2003). These patients usually exhibit both normal esophageal motility and salivary buffering capacity so vagal nerve stimulation which can result in heartburn or esophagitis is typically not seen. For this reason, patients with LPR often do not seek treatment and can go undiagnosed for the condition (Postma, Tomek, Belafsky, \& Koufman, 2001). As for reported symptoms seen in LPR patients, 
these are mainly extraesophageal and are found in the head and neck regions. The most common include dysphonia, chronic postnasal drip, sinusitis, sore throat with pain and/or dysphagia, hoarseness, globus pharyngeus, chronic cough, Eustachian tube dysfunction, and asthma-like symptoms with shortness of breath (Belafsky, Postma, Amin, \& Koufman, 2002). Clinical findings are another key difference between GERD and LPR. While the majority of patients with GERD exhibit esophagitis, only $12-18 \%$ of patients with LPR show endoscopic evidence. Of these, another $7 \%$ exhibited signs of Barrett esophagus, while the remaining $81 \%$ presented with normal esophageal epithelial tissues upon biopsy (Koufman, 1991; Koufman, Belafsky, Bach, Daniel, \& Postma, 2002).

The pathophysiology of LPR is also different than GERD and is typically attributed to a defect or dysfunction of the upper esophageal sphincter which allows gastric contents to enter the upper airways (Ocak, Kubat, \& Yorulmaz, 2015). While the esophagus features a number of protective mechanisms which prevent injury to the mucosa, the laryngeal and pharyngeal structures do not and are more susceptible to damage from reflux of stomach contents (Ossakow, Elta, Colturi, Bogdasarian, \& Nostrant, 1987). Esophageal mucosa exhibits a critical pH of 4.0, the point at which cell injury occurs. In comparison, damage to laryngeal epithelium occurs at a $\mathrm{pH}$ of 5.0 which makes it ten times more susceptible to acid attacks (Axford, et al., 2001; Johnston, et al., 2003; Lillemoe, Johnson, \& Harmon, 1982). Moreover, laryngeal epithelium is up to 100 times more susceptible to pepsin damage than esophageal 
tissues, and pepsin is thought to play a key role in the pathogenesis of laryngopharyngeal reflux (Koufman, 2002 ; Samuels \& Johnston, 2009).

While pepsin exhibits maximum activity at a $\mathrm{pH}$ of 2.0 , it is inactivated at a $\mathrm{pH}$ of 6.5 and stable until a pH of 8.0 at which point it becomes denatured. In comparison, the laryngopharyngeal tissues exhibit a pH of 6.4 and, following a reflux event, pepsin in these areas becomes enzymatically inactivated. Subsequent reflux episodes, however, can result in reactivation due to a decrease in $\mathrm{pH}$. This is thought to result in laryngeal cell damage due to proteolytic activity which disrupts cellular cohesion (Johnston, Dettmar, Bishwokarma, Lively, \& Koufman, 2007). Over time, pepsin is internalized by laryngeal epithelial cells in a process called receptor-mediated endocytosis and stored within the cell for up to 24 hours. This mechanism may explain why many patients with laryngopharyngeal reflux are not as responsive to acid suppression therapy as those with gastroesophageal reflux disease (Johnston, Wells, Blumin, Toohill, \& Merati, 2007). Although LPR and GERD exhibit differences in symptomology, clinical findings and pathophysiology, they do share a number of risk factors as discussed previously. Table 1 outlines the primary differences between gastroesophageal reflux and laryngopharyngeal reflux. 


\begin{tabular}{|c|c|c|}
\hline & GERD & LPR \\
\hline Heartburn and/or acid reflux & Yes (diagnostic) & Uncommon \\
\hline Etiology & LES & UES \\
\hline Esophageal Motility & Impaired & Normal \\
\hline Pattern & Anytime & Daytime \\
\hline Critical pH & 4.0 & 5.0 \\
\hline Damage & Esophageal & Extraesophageal \\
\hline
\end{tabular}

Table 1: Comparison of GERD and LPR 


\section{DENTAL MANIFESTATIONS}

As a review, there are four proposed types of tooth wear which can be classified into three causal categories. The first is mechanical loss and includes both attrition and abrasion. The second is chemical loss which includes erosion, the chemical dissolution of tooth material without bacterial involvement (Pindborg, 1970). The third is biomechanical loss which includes the theory of abfraction to explain non-carious cervical lesions (Grippo, 1991). Each mechanism presents with unique clinical characteristics but literature suggests that tooth wear is multifactorial. Although independent in origin, erosion typically works synergistically with abrasion and attrition as it enhances physical wear (Curtis, Jayanetti, Chu, \& Staninec, 2011). In fact, current literature disputes the theory of abfraction and attributes the presence to non-carious cervical lesions to a combination of erosion and toothbrush abrasion (Bartlett \& Shah, 2006). Lab studies have shown that toothbrush abrasion has been shown to result in $50 \%$ greater loss of tooth structure during acid exposure than brushing alone (Eisenburger, Shellis, \& Addy, 2003). Because erosion is a multifactorial process, it can be difficult for the clinician to recognize. As a consequence, it is often misdiagnosed and can result in restorative treatment which can compromise the vitality of the tooth (Cardoso, Canabarro, \& Myers, 2000).

As for the etiology of erosion, there are a variety of exogenous and endogenous sources that must be ruled out when treating a potential patient for erosion. Extrinsic erosion is the result of exogenous acids found in the environment, most commonly 
acidic foods, beverages and snacks. This can include behavioral causes such as citrus sucking, fruit mulling, soda swishing, and eating pickled foods (Søvik, Skudutyte-Rysstad, Tveit, Sandvik, \& Mulic, 2015). Environmental causes are numerous and can include industries that result in high acid vapor levels such as the manufacture of textiles, batteries, fertilizers, rubber, or drugs such as methamphetamines (Cate Bruggen, 1968). Professional swimmers are also at risk due to highly chlorinated swimming pools, which, when combined with water, forms hydrochloric acid (Geurtsen, 2000; Centerwall, Armstrong, Funkhouser, \& Elzay, 1986). Intrinsic erosion is the result of endogenous stomach acids and is typically caused by vomiting, regurgitation, reflux or rumination (Mahoney \& Kilpatrick, 2003).

Dental erosion is considered a normal physiological process that occurs throughout life and is considered the most common cause of tooth wear in the Western world. When this process results in excessive and rapid loss of tissues, however, this is considered a pathological condition (Paryag \& Rafeek, 2014). The literature shows a strong correlation between GERD and dental erosion, with a median prevalence of $24 \%$ in a large range of age groups. When viewed by age demographics, adults exhibited a range of $21-83 \%$, while children demonstrated $14-87 \%$ (Pace, Pallotta, Tonini, Vakil, \& Bianchi Porro, 2008). Although tooth erosion due to reflux was first reported in 1933, there are still barriers to successful management (Bodecker, 1933). Because it is typically a slowly-progressing phenomenon, many patients are unaware of the destruction and typically do not present with a chief complaint of "erosion". Moreover, there is a general lack of emphasis in dental curricula or continuing education programs 
and the average dentist may be unaware of strategies for early diagnosis and treatment. Finally, there is a lack of incentive for the clinician who is paid by the insurance companies for restorative procedures, and not for conservative management (Curtis, Jayanetti, Chu, \& Staninec, 2011).

When viewed at the surface of the tooth, acid advancement first strips the protective dental pellicle and then displaces the saliva which has a lower surface tension and contact angle (Ranjitkar S, 2012). The $\mathrm{pH}$ of gastric acid can vary between 1.5 and 3.5 , but is still much lower than the critical pH of hydroxyapatite and fluoroapatite which are generally accepted at 5.5 and 4.5 , respectively (Kutsch, Chaiyabutr, \& Milicich, 2013) (Jones, Lekkas, Hunt, Mclntyre, \& Rafir, 2002). This results in demineralization and the loss of calcium and phosphate ions from the mineral surface. This is an irreversible process and over time, forms dished-out lesions on the enamel surface (Ranjitkar S, 2012). Continued acid exposure not only results in clinically visible defects, but results in a significant reduction in microhardness which makes the softened surface more prone to mechanical wear from abrasion or attrition (Maupomé, Díez-de-Bonilla, TorresVillaseñor, Andrade-Delgado, \& Castaño, 1998). While some sources suggest that acid reflux promotes the growth of Streptococcus mutans and results in an increase in dental caries, others suggest a lack of a relationship between them (Muñoz, et al., 2003; Schroeder, 1995). 


\section{Stages of Erosion}

Clinical signs of early or mild erosion begin with an initial loss of tooth luster that is soon followed with a smooth glazed appearance as the enamel is lost (Eccles \& Jenkins, 1974). Eventually, morphologic features tend to disappear including developmental ridges, flattening of convex surfaces, and a change in color may be noted due to the dentin showing through the thin, translucent enamel shell. The end result is a melted appearance with slightly concave defects visible on some surfaces as seen in image 1 (Lussi, Dental erosion clinical diagnosis and case history taking, 1996).

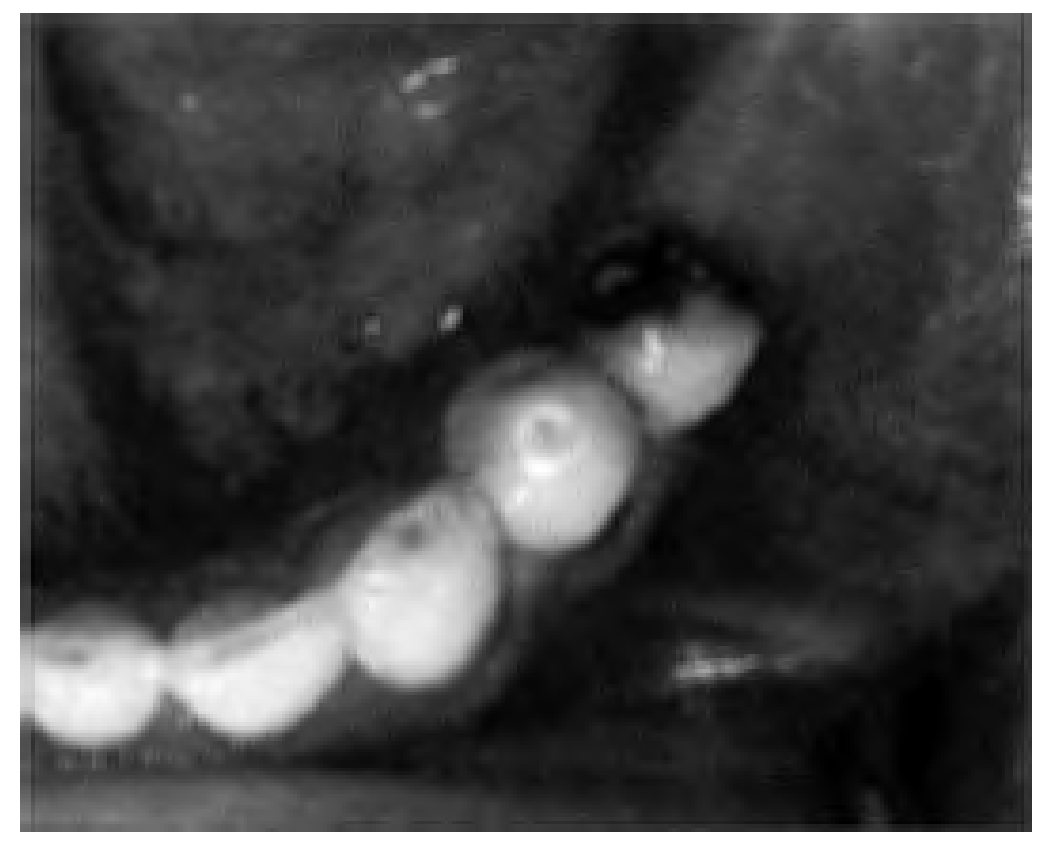

Figure 1: Early Erosion

Clinical signs of intermediate erosion include more exaggerated rounding of the cusp and groove morphology, concavities or cupping on the occlusal or incisal surfaces, and loss of surface enamel with exposed dentin surfaces and tooth sensitivity as shown in figure 2. Continued erosion results in the formation of reactionary and reparative 
dentin which obturate the dentinal tubules and result in discoloration and sclerotic dentin (Ganss, Lussi, \& Schlueter, 2014).

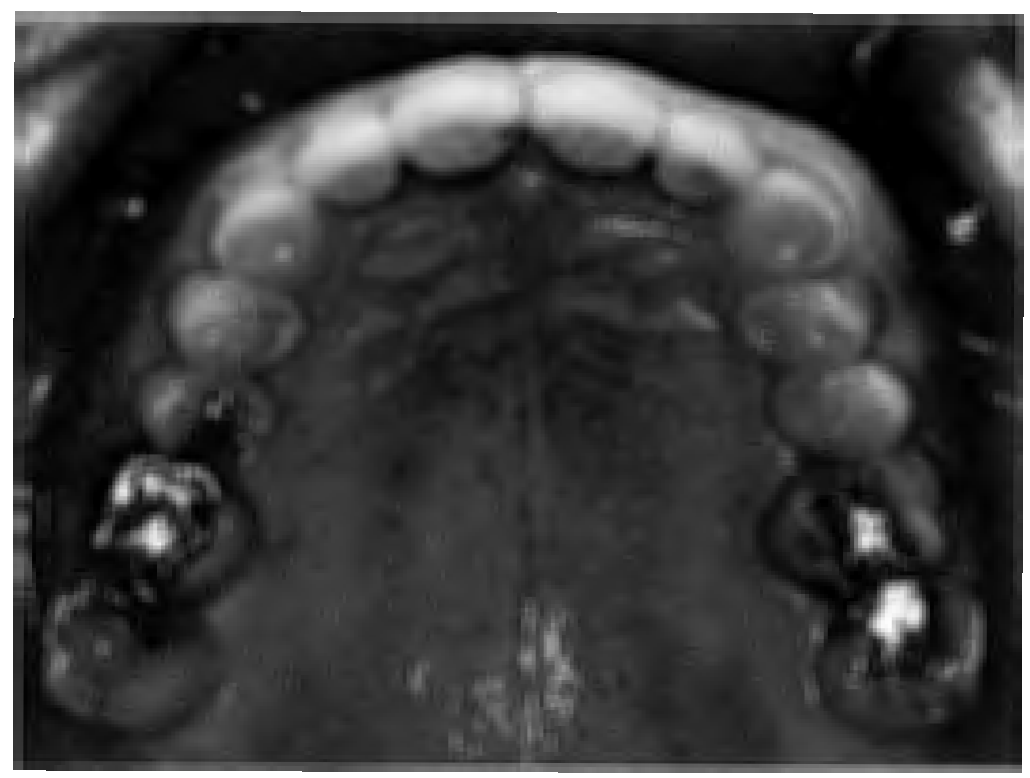

Figure 2: Intermediate Erosion

Clinical signs of advanced or severe erosion include gross destruction of the hard tissues which results in compromised esthetics and function, and a possible loss of occlusal vertical dimension. Furthermore, if erosive wear exceeds the reparative capacity of the pulpal tissues, frank, or near, pulp exposure can occur. This may result in endodontic complications such as sensitivity, pain, pulpal inflammation and necrosis (Jaeggi \& Lussi, 2006). In fact, endodontic sequelae are estimated to occur in $10 \%$ of patients with significant erosive wear (Sivasithamparam, Harbrow, Vinczer, \& Young, 2003). Figure 3 demonstrates evidence of root canal therapy on the remaining maxillary dentition in a patient that presented with undiagnosed reflux disease. 


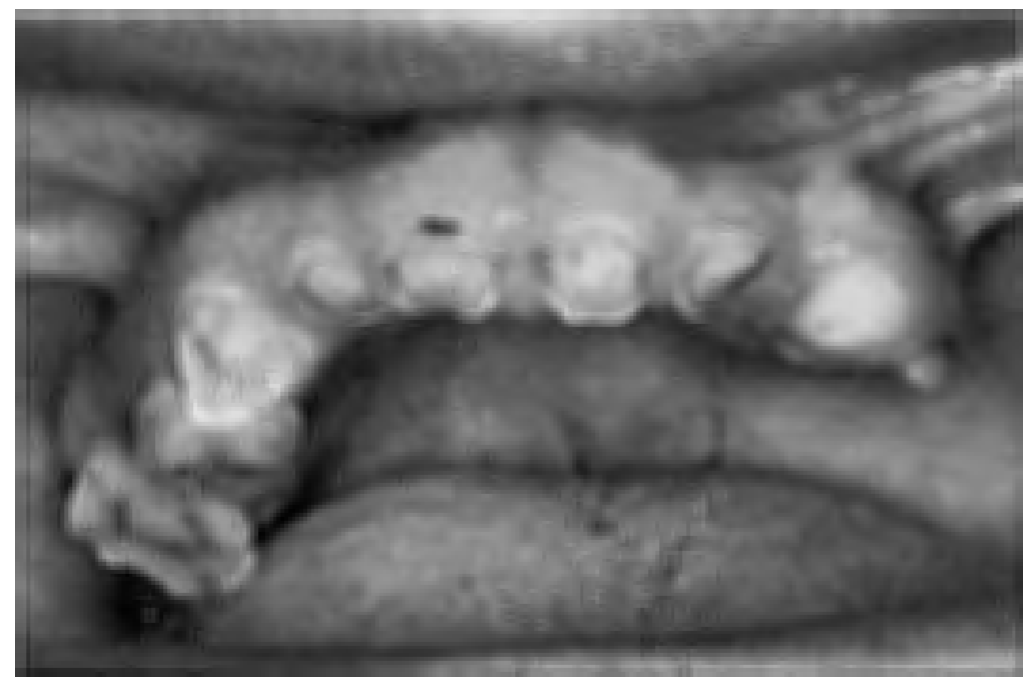

Figure 3: Advanced Erosion

\section{Other Dental Findings}

Another tell-tell sign of advanced erosion is the presence of raised restorations above the level of adjacent tooth surfaces, often referred to as amalgam islands as shown in Figure 4 (Lazarchik \& Filler, 1997). In addition, these patients may also present with a preserved enamel band along the gingival margin as also shown in Figure 4 . This is thought to be due to plaque remnants which might act as a protective diffusion barrier, or due to the sulcular fluid which has an acid-neutralizing $\mathrm{pH}$ between 7.5 and 8.0 (Lussi, Jaeggi, \& Zero, 2004). 


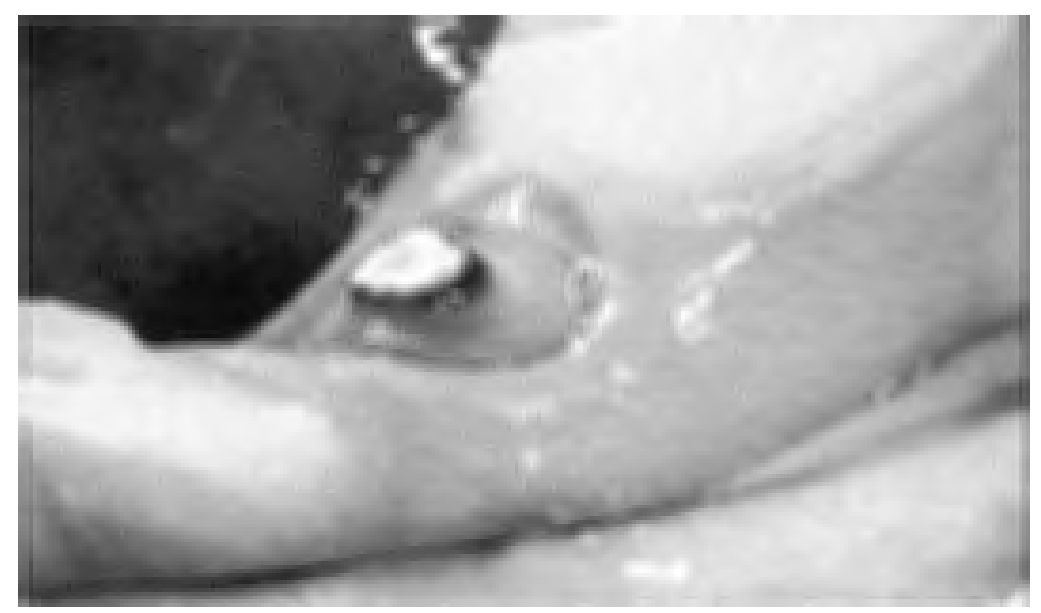

Figure 4: Amalgam Island

Furthermore, oral mucosal lesions may result from acid and pepsin exposure and can result in dry oral mucosa with a keratotic appearance of the gingival tissues (Rabine \& Nostrant, 2009). Histologic studies of palatal mucosa in reflux patients has found a greater prevalence of epithelial atrophy in reflux patients as compared to control subjects. Other findings include deepened epithelial crests in the connective tissues and a high incidence of fibroblasts (Silva, Damante, Stipp, Tolentino, Carlotto, \& Fleury, 2001). Furthermore, there is some evidence that burning mouth syndrome might be associated with reflux (Gurvits \& Tan, 2013). Like the laryngeal mucosa, damage to the oral mucosa may be primarily mediated by pepsin and dependent on $\mathrm{pH}$ within the oral cavity (Ocak, Kubat, \& Yorulmaz, 2015 ; Jiang, et al., 2011). 


\section{MEDICAL COMPLICATIONS}

In addition to dental manifestations, there are a number of potential medical complications in patients with reflux disease which can include otitis media, constriction of the larynx with scarring of the vocal cords, erosive esophagitis with narrowing as the result of scar formation and the development of peptic ulcers (Bardhan, Strugala, \& Dettmar, 2012). In addition, patients with LPR may exhibit persistent laryngopharyngitis and recurrent pneumonia due to the aspiration of gastric contents (Fass \& Dickman, 2006). A particular concern of patients with reflux is the development of Barrett esophagus which occurs in the distal esophagus as shown in Figure 5. This is thought to be the result of the body's reaction to chronic exposure of gastric contents and results in metaplasia of the normal stratified squamous epithelium to simple columnar epithelium with goblet cells as found in the intestinal tract. This is characterized by aneuploidy or an abnormal number of chromosomes and is considered a pre-malignant condition as it is the strongest risk factor for esophageal adenocarcinoma (Prasad, Bansal, Sharma, \& Wang, 2010; Rustgi \& Sun, 2009). Furthermore, up to $25 \%$ of patients with Barrett esophagus and $40 \%$ of all esophageal adenocarcinomas occur in patients with or without minimal previous reflux symptoms which gives cause for alarm in patients with silent reflux (Gerson, Shetler, \& Triadafilopoulos, 2002; Lagergren, Bergstrom, Lindgren, \& Nyren, 1999). 


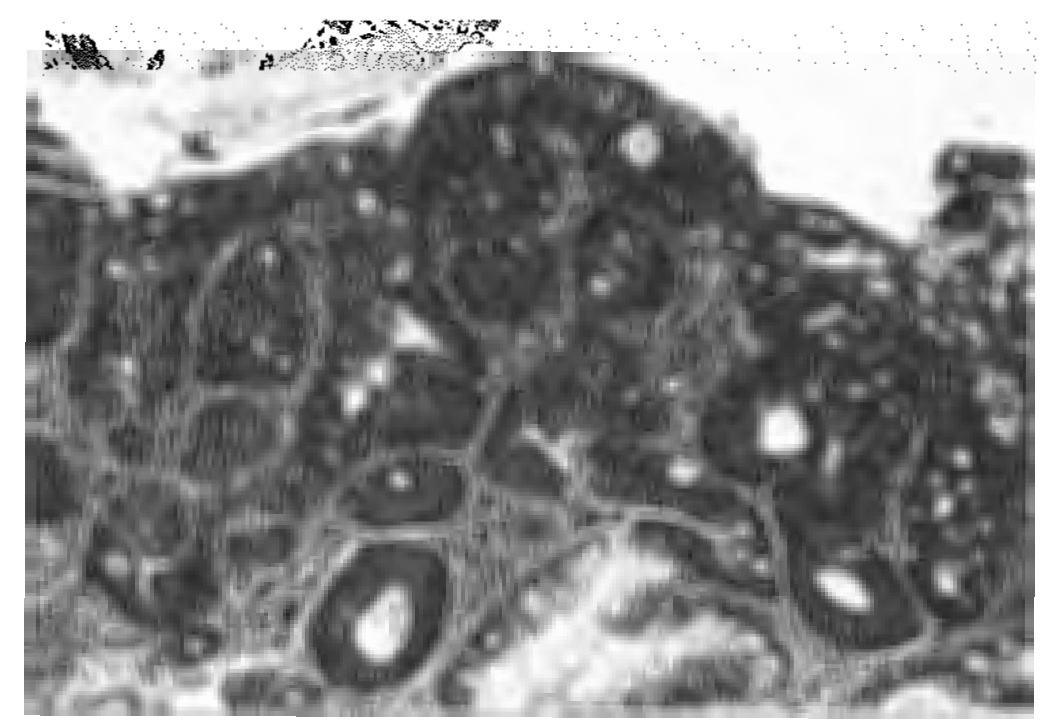

Figure 5: Barrett esophagus exhibiting simple columnar epithelium with goblet cells

More serious, but less frequent, findings in patients with LPR include vocal cord nodules, posterior laryngitis, laryngospasms, subglottic stenosis, arytenoid fixation, and laryngeal cancer (Metz, Childs, Ruiz, \& Weinstein, 1997 ; Little, Koufman, Kohut, \& Marshalf, 1985). Although the relationship between LPR and laryngeal squamous cell carcinoma (SCC) has never been proven, pepsin is thought to be a significant risk factor in the development of cancer (Ward \& Hanson, 1988). Studies show that pepsin promotes the proliferation of epithelial cell cultures with associated gene expression changes that result in neoplasia (Johnston, Yan, Hoekzema, Stoner, Blumin, \& Bock, 2012). 


\section{DIAGNOSIS}

Although the clinician may suspect erosion due to reflux, the actual diagnosis must be done by the patient's physician based on the medical history and exam. A presumptive diagnosis of GERD is often made by symptomology alone, or by placing the patient on antacids or a proton pump inhibitor (PPI) test, where the patient is prescribed a proton pump inhibitor for a short period of time to see if it resolves gastric symptoms (Sweis, Fox, Anggiansah, \& Wong, 2011). In the majority of patients, this is considered sufficient for diagnosis of GERD but if the diagnosis is uncertain or the patient presents with atypical symptoms such as those seen in LPR, the physician may refer to a gastroenterologist for more invasive tests. These may include endoscopy, barium swallow or $\mathrm{pH}$ monitoring to evaluate function and presentation. Endoscopy is useful in the detection of erosive esophagitis, as well as the presence of Barrett esophagus or hiatal hernia. It is often used to sample for the presence of Helicobacter pylori (Wenner, Johnsson, Johansson, \& Oberg, 2007). When a structural abnormality such as stricture, hiatal hernia, ulceration or erosion is suspected, a barium esophagram, or upper Gl series, is often useful in diagnosis. Although this test has proven practical in patients that exhibit a high level of reflux, it demonstrates insufficient sensitivity and specificity to reveal mild irritation as seen in patients with abnormal degrees of acid reflux such as that seen in LPR (Johnston, Troshinsky, Castell, \& Castell, 1996).

As for clinical diagnostic tests, impedance $\mathrm{pH}$ testing is considered the gold standard and is very useful in determination of daily reflux levels and patterns in 
patients with reflux disease (Spencer, 1969). Historically, this has been done with a transnasal catheter which involves surgical placement of a small catheter through the nose and embedding it into the distal esophagus. Once in place, a sensor detects acid $\mathrm{pH}$ levels and sends this information to a computer which records the findings over a 24 hour period. Due to the wired catheter, this procedure is inconvenient to the patient and limits daily activities. More recently, wireless $\mathrm{pH}$ probes have gained in use and are typically implanted in the distal esophagus and transmit information to a small receiver via radiotelemetry. This not only minimizes disruption to the patient's daily activities, but offers greater sensitivity and specificity than traditional transnasal pH testing (Sweis, Fox, Anggiansah, \& Wong, 2011).

Figure 5 demonstrates the findings from a 48 hour $\mathrm{pH}$ test in a patient suspected as having silent reflux using a single $\mathrm{pH}$ probe. The red line indicates a baseline $\mathrm{pH}$ of 4.0, the point at which cell damage occurs. The yellow bands indicate meals, and the green bands denote periods of sleep. Although it is normal to see low pH levels following meals, high acid levels were evident at varying times during the day. While this patient exhibited nocturnal reflux which is typical of gastroesophageal reflux, he did not complain of heartburn or acid reflux that is diagnostic for the disease. Due to the high number of daytime refluxes during the 48 hour period and the lack of traditional GERD symptoms, the patient was diagnosed with laryngopharyngeal reflux. 


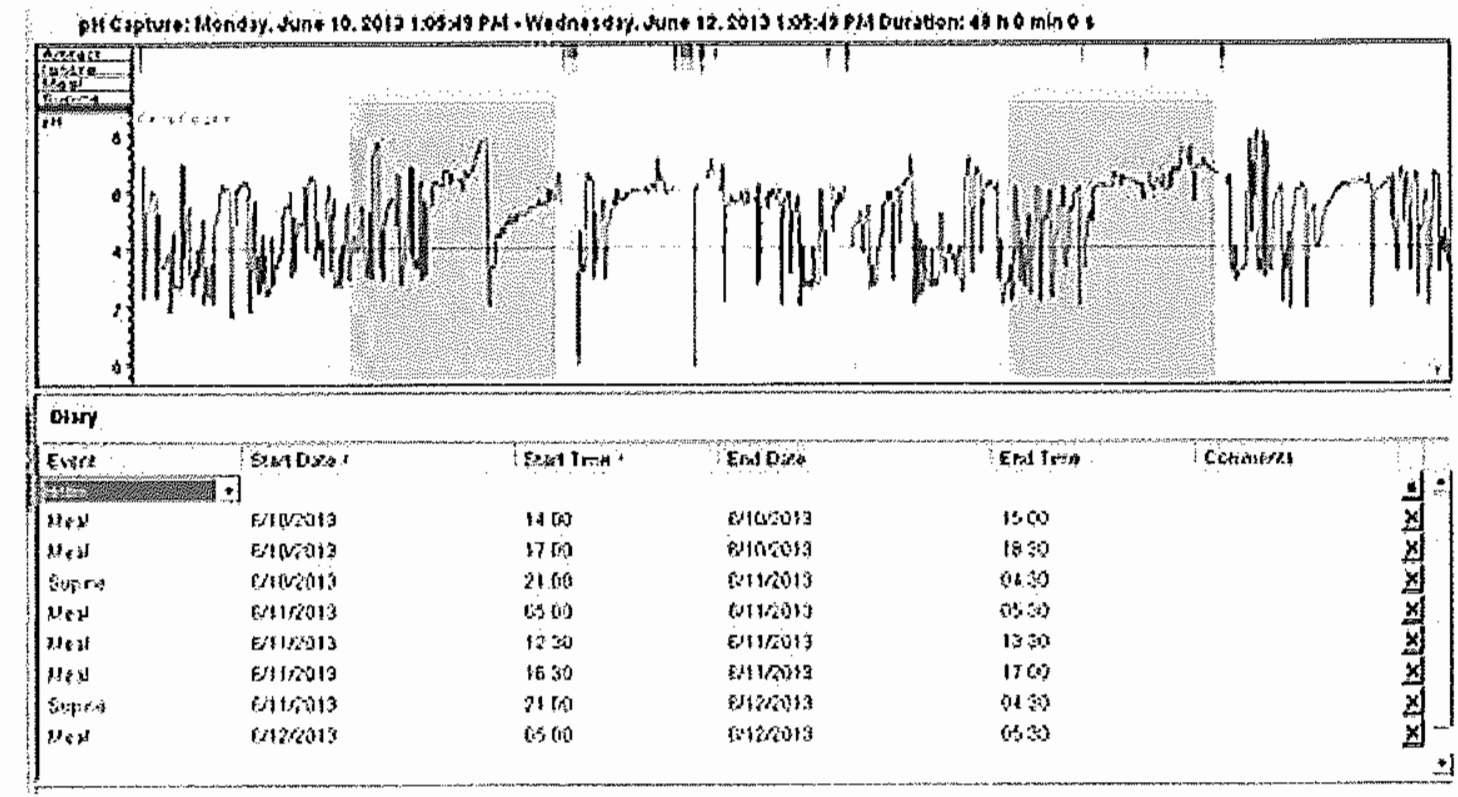

Figure 5: 48 Hour pH Testing

In comparison to GERD, diagnosis of LPR is more challenging due to the presence of atypical symptoms which typically do not respond to empirical therapy with proton pump inhibitors. In fact, less than half of patients with LPR experience full resolution of symptoms in a four month period (Belafsky, Postma, \& Koufman, 2001). While singleprobe $\mathrm{pH}$ testing is often used in the diagnosis of LPR, studies have shown it lacks the sensitivity needed for an accurate diagnosis. In one study of conventional ambulatory 24 hour $\mathrm{pH}$ monitoring, false negative results were reported in $15-30 \%$ of patients with LPR (Ocak, Kubat, \& Yorulmaz, 2015 ). The current gold standard in the diagnosis of LPR is 24 -hour double probe $\mathrm{pH}$ monitoring which was first used to document extraesophageal reflux in 1986 (Koufman, 1991). Unlike a single-probe test, this method utilizes two $\mathrm{pH}$ probes, one at the proximal end of the esophagus, and the other at the distal end (Postma, Belafsky, Aviv, \& Koufman, 2002). 
Although endoscopy, $\mathrm{pH}$ monitoring and barium swallow radiographs are highly diagnostic, each involves a certain amount of risk to the patient, from surgical complications to radiation exposure. More importantly, none of these tests correlate oral findings such as erosion to the reflux process so are of limited diagnostic use to the dentist. In the past, litmus paper has been used as a minimally invasive method to check for the presence of acid in the oral cavity. Although this is a simple test which lacks strong sensitivity or specificity, it could indicate the need for further evaluation of potential reflux disorders (James \& Ewer, 1999). More recently, immunoserologic pepsin detection tests have gained in popularity as a cost effective and minimally invasive diagnostic method. These tests are similar to an over-the-counter pregnancy test, but instead of testing for human chorionic gonadotropin (hCG), these tests measure the presence of pepsin in the saliva. The results can typically be read within 10 minutes and exhibit high sensitivity and specificity, making this a potentially useful diagnostic tool in patients that don't present with classic GERD symptoms such as LPR (Ocak, Kubat, \& Yorulmaz, 2015 ; Knight, Lively, Johnston, Dettmar, \& Koufman, 2005). 


\section{TREATMENT}

Treatment of GERD typically begins with dietary changes that restrict spicy or acidic foods, and beverages such as alcohol, caffeine, chocolate and carbonated drinks. Although diet has been shown to precipitate acid secretion in some patients, there is little supporting evidence that dietary intake results in clinical manifestations of GERD (Festi, et al., 2009). Regardless, this first-line treatment usually includes portion control and moderation of even mildly acidic foods such as fatty meats and dairy products. In addition, a well-balanced diet with neutral-to-alkaline foods which neutralize stomach acid and inactivate pepsin is often recommended to the patient. For patients that exhibit nighttime reflux, eating meals $2-3$ hours before bedtime and walking immediately after meals may help with symptoms (Kahrilas, et al., 2008).

Suggested lifestyle modifications for obese patients typically include an enhanced exercise regimen in order to reduce body weight and intra-abdominal pressure. While moderate exercise is shown to be efficacious, strenuous exercise may induce GERD symptoms (Pandolfino, Bianchi, Lee, Hirano, \& Kahrilas, 2004; Ravi, Stuart, Byrne, \& Reynolds, 2005). Another common recommendation to patients with nocturnal reflux is to elevate the head of the bed or to support the head using pillows. While this may work for some patients, there is a low level of evidence to support it (Hamilton, Boisen, Yamamoto, Wagner, \& Reichelderfer, 1988). In comparison, literature shows a definite relationship between increased body mass index and GERD symptoms (Corley \& Kubo, 2006 ; Hampel, Abraham, \& El-Serag, 2005). Of the many 
dietary and lifestyle recommendations made for patients with GERD, only weight loss shows a moderate level of evidence in the literature (Kaltenbach, Crockett, \& Gerson, 2006).

As for pharmacologic therapy, $\mathrm{H} 2$ receptor blockers and proton pump inhibitors are typically used to treat reflux disease by inhibiting acid secretion. Of the two, PPIs are the most efficacious and exhibit the highest level of evidence for use in treatment of GERD symptoms (Katz, Gerson, \& Vela, 2013). GERD is often diagnosed by placing the patient on antacids or a proton pump inhibitor (PPI) test, where the patient is prescribed a proton pump inhibitor for a short period of time to see if it resolves gastric symptoms (Sweis, Fox, Anggiansah, \& Wong, 2011). There are two major treatment options and the first is called a step-up approach. This begins with an over the counter $\mathrm{H} 2$ receptor blocker and if the condition fails to improve, therapy is stepped up to a more powerful proton-pump inhibitor. The other model is called a step-down approach and is opposite as it begins with the more potent drug. When the patient has been symptom free for a period of time, they are stepped down to a less powerful medication. For patients with moderate-to-severe reflux disease, many physicians favor the second approach (Inadomi, et al., 2001; Sonnenberg, Inadomi, \& Becker, 1999). In patients with severe reflux, surgical correction is sometimes performed when medical therapy has failed. There are a number of procedures which are used but the most severe is the Nissen or complete fundoplication. In this method, the upper part of the stomach is wrapped, or plicated, around the lower end of the esophagus and sutured in place. This serves to reinforce the closing function of the lower esophageal sphincter 
(Abbas, et al., 2004). Although this is considered a safe and effective procedure, it can result in side effects such as gas and bloating (Waring, 1999).

In comparison to GERD, treatment of LPR is much more difficult as empirical therapy with proton pump inhibitors is not as effective. In those patients, dosage is often inadequate, and/or the duration of treatment is insufficient (Koufman, Aviv, Casiano, \& Shaw, 2002). Despite this fact, PPIs are considered superior to $\mathrm{H}_{2}$ receptor blockers in patients with moderate to severe LPR. In fact, histamine receptor antagonists provide benefit to only about $50 \%$ of the LPR patients that respond to treatment (Scott \& Gelhot, 1999; Klinkenberg-Knol \& Meuwissen, 1989; Smith, Gavey, Nwokolo, \& Pounder, 1990; Wilder-Smith, Ernst, Gennoni, Zeyen, Halter, \& Merki, 1990). Regardless, LPR symptoms resolve slowly and fewer than half of patients treated with PPIs exhibit full recovery after 4 months of treatment (Belafsky, Postma, \& Koufman, 2001). LPR can be classified into three groups; minor, major and lifethreatening as based on symptomology and findings (Postma, Johnson, \& Koufman, 2002). Treatment options vary from conservative to aggressive, depending on the classification. According to the literature, diet and lifestyle modifications show limited efficacy with a few exceptions. In one study, it was found that chewing sugarless gum consistently increases esophageal and pharyngeal $\mathrm{pH}$, making it a non-invasive adjunctive therapy to laryngopharyngeal reflux (Smoak \& Koufman, 2001). Although the level of evidence is low for changes in diet when treating GERD, a strict low-acid diet has been shown to have therapeutic benefits in the treatment of PPI-resistant LPR. Because 
pepsin is active up to a $\mathrm{pH}$ of 6.5 , a virtually acid free diet demonstrates $95 \%$ improvement of symptoms in test patients (Koufman, 2011).

In regards to dental management, tooth wear is multifactorial and patients exhibiting erosion must be correctly assessed along with the actual etiology of wear (Litonjua, Andreana, Bush, \& Cohen, 2003). This is typically followed by dietary counseling and/or referral to the patient's physician or to a gastroenterologist for further evaluation. Patient education should include oral hygiene instructions and may include the recommendation not to brush immediately after eating acidic foods, or after a reflux episode as the tooth is more susceptible to abrasion (Eisenburger, Shellis, \& Addy, 2003). Before considering dental treatment, it is important that the patient be correctly managed by his or her physician prior to beginning any restorative work. Thus, the medical condition should be treated before oral rehabilitation. Barrier considerations should include the disuse of abrasive toothpastes and some sort of tray or night guard (Curtis, Jayanetti, Chu, \& Staninec, 2011). Fluoride products are also indicated to facilitate remineralization, and products such as gum containing calcium phosphate serve to enhance mineral precipitation of eroded enamel (Prestes, Souza, Comar, Salomão, Rios, \& Magalhães, 2013).

Materials selection is also important when considering restorations in a patient with erosion from reflux disease. Some authors advocate composite resin as the gold standard in cases of mild erosion due to its retention and enamel margin sealing (Broliato, et al., 2008). Unfortunately, in cases with moderate-to-severe erosive tooth 
loss, the presence of sclerotic dentin results in lower bond strengths (Tay \& Pashley, 2004). In these cases, full coverage restorations are often indicated to restore lost tooth structure and function which may require adjunctive treatment such as root canal therapy and/or crown lengthening (Curtis, Jayanetti, Chu, \& Staninec, 2011). When choosing a luting agent, glass ionomer cements are often chosen due to their adhesive capacity and ease of use. Unfortunately, they exhibit erosion rates that are only slightly lower than enamel or dentin (Eisenburger, Addy, \& Rossbach, 2003). A similar comparison between resin modified glass ionomer, polyacid-modified resin composite (compomer) and resin composite found that resin composite cements exhibit the least amount of leakage and may be preferable due to their inherent low solubility over time (Yap, Lim, \& Neo, 1995).

Placement of preparation finish lines is yet another consideration when using full coverage restorations. In the past, anecdotal reports advocated the placement of subgingival finish lines in an effort to minimize further erosive wear. The most prevalent theory is that the sulcular fluid has a pH between 7.5 and 8.0 and works to neutralize acids, although there is nothing in the literature to support this practice. While subgingival placement of finish lines may mitigate further erosion, this can result in periodontal issues as well as promote the incidence of new caries (Charbeneau G, 1975; Silness, 1970; Newcomb, 1974). In one of the classic articles on margin placement, it was determined that subgingival margins should be generally be avoided except for certain situations such as esthetic demands, removal of caries, subgingival tooth fracture, coverage of an existing subgingival restoration, to gain coronal crown length, 
or to provide for a more favorable restoration contour (Becker \& Kaldahl, 2005).

Regardless of philosophy, the best treatment for the dentist is to ensure the patient's

reflux is controlled with the appropriate referrals and medication to address the disease in the first place. 


\section{CONCLUSIONS}

In conclusion, laryngopharyngeal reflux (LPR) is similar to gastroesophageal reflux disease (GERD) in that it allows endogenous stomach acids to enter the upper airways, but does usually not present with the usual symptoms which would cause a patient to seek treatment. As such it can go undiagnosed and result in a variety of dental and medical complications. Because of the association with Barrett's esophagus, esophageal and laryngeal carcinoma, this disease has the potential to be considered a silent killer. 


\section{REFERENCES}

Abbas, A., Deschamps, C., Cassivi, S., Allen, M., Nichols, F., Miller, D., et al. (2004). The role of laparoscopic fundoplication in Barrett's esophagus. Annals of Thoracic Surgery, $77(2)$, 393-396.

Allen, M., Mellow, M., Robinson, M., \& Orr, W. (1987). Comparison of calcium channel blocking agents and an anticholinergic agent on oesophageal function. Alimentary Pharmacology \& Therapeutics, $1(2), 153-159$.

Allen, M., Mellow, M., Robinson, M., \& Orr, W. (The American Journal of Gastroenterology). The effect of raw onions on acid reflux and reflux symptoms. 85(4), 377-380.

Axford, S., Sharp, N., Ross, P., Pearson, J., Dettmar, P., Panetti, M., et al. (2001). Cell biology of laryngeal epithelial defenses in health and disease: preliminary studies. The Annals of Otology, Rhinology, and Laryngology, 110(12), 1099-1108.

Bardhan, K., Strugala, V., \& Dettmar, P. (2012). Reflux Revisited: Advancing the Role of Pepsin. The International Journal of Otolaryngology, 1-13.

Bartlett, D. (2006). Intrinsic Causes of Erosion. In Bartlett, \& A. Lussi (Ed.), Dental Erosion From Diagnosis to Therapy (Vol. 20, pp. 119-139). Basel, Switzerland: Karger.

Bartlett, D., \& Shah, P. (2006). A critical review of non-carious cervical (wear) lesions and the role of abfraction, erosion, and abrasion. Journal of Dental Research, 85(4), 306-312.

Bauman, N., Sandler, A., Schmidt, C., \& Maher, J. (1994). Reflex laryngospasm induced by stimulation of distal esophageal afferents. The Laryngoscope, 104, 209-214.

Belafsky, P., \& Postma, G. (2003). The laryngeal and esophageal manifestations of Sjögren's syndrome. Current Rheumatology Reports, 5(4), 297-303.

Belafsky, P., Postma, G., \& Koufman, J. (2001). Laryngopharyngeal reflux symptoms improve before changes in physical findings. The Laryngoscope, 111(6), 979-981.

Belafsky, P., Postma, G., Amin, M., \& Koufman, J. (2002). Symptoms and findings of laryngopharyngeal reflux. Ear, Nose \& Throat Journal, 81(9), 10-13.

Bodecker, C. (1933). Dental erosion: its possible causes and treatment. Dental Cosmos, 75, 1056-1062.

Broliato, G., Volcato, D., Reston, E., Kramer, P., Marquezan, M., Ruzzarin, F., et al. (2008). Esthetic and functional dental rehabilitation in a patient with gastroesophageal reflux. Quintessence International, 39(2), 131-137. 
Buthpitiya, A., Stroud, D., \& Russell, C. (1987). Pharyngeal pump and esophageal transit. . Digestive Diseases and Sciences, 32(11), 1244-1248.

Cardoso, A., Canabarro, S., \& Myers, S. (2000). Dental erosion: diagnostic-based noninvasive treatment. Practical Periadontics and Aesthetic Dentistry, 12(2), 223-228.

Cate Bruggen, H. J. (1968). Dental Erosion in Industry. British Journal of Industrial Medicine, $25(4), 249-266$.

Centerwall, B., Armstrong, C., Funkhouser, G., \& Elzay, R. (1986). Erosion of dental enamel among competitive swimmers in gas-chlorinated swimming pools. American Journal of Epidemiology, 123(4), 641-647.

Chandrasoma, P. (2010). The pathology of gastroesophageal reflux disease. In P. Chandrasoma, \& T. DeMeester, GERD: Reflux to Esophageal Adenocarcinoma (pp. 276-291). Salt Lake City, Utah: Academic Press.

Cho, J., Kim, H., Ko, G., Woo, M., Moon, C., Kim, Y., et al. (2011). Old age and male sex are associated with increased risk of asymptomatic erosive esophagitis: analysis of data from local health examinations by the Korean National Health Insurance Corporation. Journal of Gastroenterology and Hepatology, 26(6), 1034-1038.

Choi, J., Jung, H., Song, E., Shim, K., \& Jung, S. (2013). Determinants of symptoms in gastroesophageal reflux disease: nonerosive reflux disease, symptomatic, and silent erosive reflux disease. European Journal of Gastroenterology \& Hepotology, 25(7), 764771.

Corley, D., \& Kubo, A. (2006). Body mass index and gastroesophageal reflux disease: a systematic review and meta-analysis. The American Journal of Gastroenterology, 101(11), 2619-2628.

Curtis, D., Jayanetti, J., Chu, R., \& Staninec, M. (2011). Decision-making in the management of the patient with dental erosion. Journal of the California Dental Association, 39(4), 259. 265.

Dean, B., Aguilar, D., Johnson, L., McGuigan, J., Orr, W., Fass, R., et al. (2008). Night-time and daytime atypical manifestations of gastro-oesophageal reflux disease: frequency, severity and impact on health-related quality of life. Alimentary Pharmacology and Therapeutics, 27(4), 327-337.

Demeester, T., Johnson, L., Joseph, G., Toscano, M., Hall, A., \& Skinner, D. ( 1976). Patterns of gastroesophageal reflux in health and disease. Annals of Surgery, 184(4), 459-470. 
Dent, J., Dodds, W., Friedman, R., Sekiguchi, T., Hogan, W., Arndorfer, R., et al. (1980). Mechanism of gastroesophageal reflux in recumbent asymptomatic human subjects. The Journal of Clinical Investigation, 65(2), 256-267.

Dodds, W., Dent, J., \& Hogan, W. (1982). Mechanisms of gastroesophageal reflux in patients with reflux esophagitis. The New England Journal of Medicine, 307(25), 1547-1552.

Dunn, B. (2002). Structure and mechanism of the pepsin-like family of aspartic peptidases. Chemical Reviews, 102(12), 4431-4458.

Eccles, J., \& Jenkins, W. (1974). Dental erosion and diet. Journal of Dentistry, 2(4), 153-159.

Eisenburger, M., Addy, M., \& Rossbach, A. (2003). Acidic solubility of luting cements. Journal of Dentistry, 137-142.

Eisenburger, M., Shellis, R., \& Addy, M. (2003). Comparative study of wear of enamel induced by alternating and simultaneous combinations of abrasion and erosion in vitro. . Caries Research, 37(6), 450-455.

El-Serag, H. (2007). Time trends of gastroesophageal reflux disease: a systematic review. Clinical Gastroenterology and Hepatology, 5(1), 17-26.

El-Serag, H., Sweet, S., Winchester, C., \& Dent, J. (2014). Update on the epidemiology of gastrooesophageal reflux disease: a systematic review. Gut, 63(6), 871-880.

Fass, R., \& Dickman, R. (2006). Clinical consequences of silent gastroesophageal reflux disease. Current Gastroenterology Reports , 8(3), 195-201.

Fass, R., Achem, S., Harding, S., Mittal, R., \& Quigley, E. (2004). Review article: supraoesophageal manifestations of gastro-oesophageal reflux disease and the role of nighttime gastro-oesophageal reflux. Fass $R$, Achem $S R$, Harding $S$, Mittal RK, Quigley $E$ (2004). Review article: supra-oesophAlimentary Pharmacology and Therapeutics, 20(9), 26-38.

Festi, D., Scaiol, I. E., Baldi, F., Vestito, A., Pasqui, F., DBiase, A., et al. (2009). Body weight, lifestyle, dietary habits and gastroesophageal reflux disease. World journal of gastroenterology, 15(4), 1690-1701.

Ganss, C., Lussi, A., \& Schlueter, N. (2014). The histological features and physical properties of eroded dental hard tissues. Monographs in Oral Science, 25, 99-107.

Gerson, L., Shetler, K., \& Triadafilopoulos, G. (2002). Prevalence of Barrett's esophagus in asymptomatic individuals. Gastroenterology, 123(2), 461-467.

Geurtsen, W. (2000). Rapid general dental erosion by gas-chlorinated swimming pool water. Review of the literature and case report. American Journal of Dentistry, 13(6), 291-293. 
Goldberg, H., Dodds, W., Gee, S., Montgomery, C., \& Zboralske, F. (1969). Role of acid and pepsin in acute experimental esophagitis. Gastroenterology, 56(2), 223-230.

Grippo, J. (1991). Abfractions: a new classification of hard tissue lesions of teeth. Journal of Esthetic Dentistry, 3(1), 14-19.

Gurvits, G., \& Tan, A. (2013). Burning mouth syndrome. World Journal of Gastroenterology, $19(5), 665-672$.

Hamilton, J., Boisen, R., Yamamoto, D., Wagner, J., \& Reichelderfer, M. (1988). Sleeping on a wedge diminishes exposure of the esophagus to refluxed acid. Digestive Diseases and Sciences, 33(5), 518-522.

Hampel, H., Abraham, N., \& El-Serag, H. (2005). Meta-analysis: obesity and the risk for gastroesophageal reflux disease and its complications. Annals of Internal Medicine, 143(3), 199-211.

Health, N. I. (1994). Digestive diseases in the United States: Epidemiology and Impact. Bethesda: National Institutes of Health.

Heidelbaugh, J., Gill, A., Van Harrison, R., \& Nostrant, T. (2008). Atypical presentations of gastroesophageal reflux disease. American Family Physician, 78(4), 483-488.

Inadomi, J., Jamal, R., Murata, G., Hoffman, R., Lavezo, L., Vigil, J., et al. (2001). Step-down management of gastroesophageal reflux disease. Gastroenterology, 121(5), 1095-1100.

Ingber, D., \& Folkman, J. (1989). How does extracellular matrix control capillary morphogenesis? Cell, 58(5), 803-805.

Jaeggi, T., \& Lussi, A. (2006). Prevalence, incidence and distribution of erosion. In A. Lussi, Dental Erosion-from diagnosis to therapy (Vol. 20, pp. 9-16). Bern, Switzerland: Karger.

James, M., \& Ewer, A. (1999). Acid oro-pharyngeal secretions can predict gastro-oesophageal reflux in preterm infants. European Journal of Pediatrics, 158(5), 371-374.

Jiang, A., Liang, M., Su, Z., Chai, L., Lei, W., Wang, Z., et al. (2011). Immunohistochemical detection of pepsin in laryngeal mucosa for diagnosing laryngopharyngeal reflux. The Laryngoscope, 121(7), 1426-1430.

Jindal, J., Milbrath, M., Shaker, R., Hogan, W., \& Toohill, R. (1994). Gastroesophageal reflux disease as a likely cause of "idiopathic" subglottic stenosis. Annals of Otology, Rhinology, and Laryngology, 103, 186-191.

Johnson, L., \& DeMeester, T. (1974). Twenty four hour pH monitoring of the distal esophagus. American Journal of Gastroenterology, 62(4), 325-332. 
Johnston, B., Troshinsky, M., Castell, J., \& Castell, D. (1996). Comparison of barium radiology with esophageal $\mathrm{pH}$ monitoring in the diagnosis of gastroesophageal reflux disease. The American Journal of Gastroenterology, 91(6), 1181-1185.

Johnston, N., Bulmer, D., Gill, G., Panetti, M., Ross, P., Pearson, J., et al. (2003). Cell biology of laryngeal epithelial defenses in health and disease: further studies. The Annals of Otology, Rhinology, and Laryngology, 112(6), 481-491.

Johnston, N., Dettmar, P., Bishwokarma, B., Lively, M., \& Koufman, J. (2007). Activity/stability of human pepsin: implications for reflux attributed laryngeal disease. The Laryngoscope, $117(6), 1036-1039$.

Johnston, N., Wells, C., Blumin, J., Toohill, R., \& Merati, A. (2007). Receptor-mediated uptake of pepsin by laryngeal epithelial cells. The Annals of Otology, Rhinology, and Loryngolgoy, 116(12), 934-938.

Johnston, N., Yan, J., Hoekzema, S. T., Stoner, G., Blumin, J., \& Bock, J. (2012). Pepsin promotes proliferation of laryngeal and pharyngeal epithelial cells. Laryngoscope, 122(6), 1-18.

Jones, L., Lekkas, D., Hunt, D., Mclntyre, J., \& Rafir, W. (2002). Studies on dental erosion: An in vivo-in vitro model of endogenous dental erosion--its application to testing protection by fluoride gel application. Australian Dental Journa, 47(4), 304-308.

Jones, L., Lekkas, D., Hunt, D., Mcintyre, J., \& Rafir, W. (Jones L, Lekkas D, Hunt D, Mclntyre J, Rafir W (2002). Studies on dental erosion: An in vivo-in vitro model of endogenous dental erosion--its application to testing protection by fluoride gel application. Australian Dental Journal, 47(4):304-308). Studies on dental erosion: An in vivo-in vitro model of endogenous dental erosion--its application to testing protection by fluoride gel application. Australian Dental Journal, 47(4), 304-308.

Kahrilas, P., Shaheen, N., Vaezi, M., Hiltz, S., Black, E., Modlin, I., et al. (2008). American Gastroenterological Association Medical Position Statement on the management of gastroesophageal reflux disease. Gastroenterology, 135(4), 1383-1391.

Kaltenbach, T., Crockett, S., \& Gerson, L. (2006). Are lifestyle measures effective in patients with gastroesophageal reflux disease? An evidence-based approach. Archives of Internal Medicine, 166(9), 965-971.

Katz, P., Gerson, L., \& Vela, M. (2013). Guidelines for the diagnosis and management of gastroesophageal reflux disease. The American Journal of Gastroenterology, 108(3), 308 328.

Klinkenberg-Knol, E., \& Meuwissen, S. (1989). Treatment of reflux oesophagitis resistant to H2receptor antagonists. Digestion, 44(1), 47-53. 
Knight, J., Lively, M., Johnston, N., Dettmar, P., \& Koufman, J. (2005). Sensitive pepsin immunoassay for detection of laryngopharyngeal reflux. The Laryngoscope, 115(8), 1473-1478.

Koufman, J. (1991). The otolaryngologic manifestations of gastroesophageal reflux disease (GERD): a clinical investigation of 225 patients using ambulatory 24-hour $\mathrm{pH}$ monitoring and an experimental investigation of the role of acid and pepsin in the development of laryngeal . The Laryngoscope, 101(4), 1-78.

Koufman, J. (2002). Laryngopharyngeal reflux is different from classic gastroesophageal reflux disease. Ear, Nose \& Throat Journal, 81(9), 7-9.

Koufman, J. (2011). Low-acid diet for recalcitrant laryngopharyngeal reflux: therapeutic benefits and their implications. Annals of Otology, Rhinology, and Laryngoloy, 120(5), 281-287.

Koufman, J., Aviv, J., Casiano, R., \& Shaw, G. (2002). Laryngopharyngeal reflux: position statement of the committee on speech, voice, and swallowing disorders of the American Academy of Otolaryngology-Head and Neck Surgery. Otolaryngology-Head and Neck Surgery, 127(1), 32-35.

Koufman, J., Belafsky, P., Bach, K., Daniel, E., \& Postma, G. (2002 ). Prevalence of esophagitis in patients with $\mathrm{pH}$-documented laryngopharyngeal reflux. The Laryngoscope, 112(9), 1606-9.

Kresina, T., \& Miller, E. (1979). Isolation and characterization of basement membrane collagen from human placental tissue. Evidence for the presence of two genetically distinct collagen chains. Biochemistry, 18(14), 3089-3097.

Kutsch, V., Chaiyabutr, Y., \& Milicich, G. (2013). Reconsidering remineralization strategies to include nanoparticle hydroxyapatite. Compendium of Continuing Education in Dentistry, 34(3), 170-176.

Lagergren, J., Bergstrom, R., Lindgren, A., \& Nyren, O. (1999). Symptomatic gastroesophageal reflux as a risk factor for esophageal adenocarcinoma. The New England Journal of Medicine, 340(11), 825-831.

Lazarchik, D., \& Filler, S. (1997). Effects of gastroesophageal reflux on the oral cavity. The American Journal of Medicine, 103(5A), 107S-113S.

Lillemoe, K., Johnson, L., \& Harmon, J. (1982). Role of the components of the gastroduodenal contents in experimental acid esophagitis. Surgery, 92(2), 276-284.

Litonjua, L., Andreana, S., Bush, P., \& Cohen, R. (2003). Tooth wear: attrition, erosion, and abrasion. Quintessence International, 34(6), 435-446. 
Little, F., Koufman, J., Kohut, R., \& Marshall, R. (1985). Effect of gastric acid on the pathogenesis of subglottic stenosis. The Annals of Otology, Rhinology, and Laryngology, 94(5), 516519.

Little, F., Koufman, J., Kohut, R., \& Marshall, R. (1985). Effect of gastric acid on the pathogenesis of subglottic stenosis. Annals of Otology, Rhinology, and Laryngology, 94, 516-519.

Logemann, J. (2014). Critical Factors in the Oral Control Needed for Chewing and Swallowing. Journal of Texture Studies, 45(3), 173-179.

Lussi, A. (1996). Dental erosion clinical diagnosis and case history taking. European Journal of Oral Sciences, 104(2), 191-198.

Lussi, A., Jaeggi, T., \& Zero, D. (2004). The role of diet in the aetiology of dental erosion. Caries Research, 38(1), 34-44.

Mahoney, E., \& Kilpatrick, N. (2003). Dental erosion: part 1. Aetiology and prevalence of dental erosion. The New Zealand Dental Journal, 99(2), 33-41.

Maupomé, G., Díez-de-Bonilla, J., Torres-Villaseñor, G., Andrade-Delgado, L., \& Castaño, V. (1998). In vitro quantitative assessment of enamel microhardness after exposure to eroding immersion in a cola drink. Caries Research, 32(2), 148-153.

Metz, D., Childs, M., Ruiz, C., \& Weinstein, G. (1997). Pilot study of the oral omeprazole test for reflux laryngitis. Otolaryngology--Head Neck Surgery, 116(1), 41-46.

Meyer, G., Austin, R., Brady, C., \& Castell, D. (1986). Muscle anatomy of the human esophagus. Journal of Clinical Gastroenterology, 8(2), 131-134.

Mokdad, A., Ford, E., Bowman, B., Dietz, W., Vinicor, F., Bales, V., et al. (2001). Prevalence of obesity, diabetes, and obesity-related health risk factors. Journal of the American Medical Association, 289(1), 76-79.

Muñoz, J., Herreros, B., Sanchiz, V., Amoros, C., Hernandez, V., Pascual, l., et al. (2003). Dental and periodontal lesions in patients with gastro-oesophageal reflux disease. Digestive and Liver Disease, 35(7), 461-467.

Mushref, M., \& Srinivasan, S. (2013). Effect of high fat-diet and obesity on gastrointestinal motility. Annals of Translational Medicine, 1(2), 14.

Naini, B., Chak, A., Ali, M., \& Odze, R. (2014). Barrett's oesophagus diagnostic criteria: endoscopy and histology. Best Practice \& Research, 29(1), 77-96.

Nozu, T., \& Komiyama, H. (2008). Clinical characteristics of asymptomatic esophagitis. Journal of Gastroenterology, 43(1), 27-31. 
Ocak, E., Kubat, G., \& Yorulmaz, I. (2015 ). Immunoserologic pepsin detection in the saliva as a non-invasive rapid diagnostic test for laryngopharyngeal reflux. Balkan Medical Journal, $32(1), 46-50$.

Ogden, C., Carroll, M., Curtin, L., McDowell, M., Tabak, C., \& Flegal, K. (2006). Prevalence of overweight and obesity in the United States, 1999-2004. Journal of the American Medical Association, 295(13), 1549-1555.

Orr, W. (2003). Sleep issues in gastroesophageal reflux disease: beyond simple heartburn control. Reviews in Gastroenterological Disorders, 3(4), S22-\$29.

Orr, W. (2005). Therapeutic options in the treatment of nighttime gastroesophageal reflux. Digestion, 72(4), 229-238.

Ossakow, S., Elta, G., Colturi, T., Bogdasarian, R., \& Nostrant, T. (1987). Esophageal reflux and dysmotility as the basis for persistent cervical symptoms. The Annals of Otology, Rhinology, and Laryngology, 96(4), 387-392.

Pace, F., Pallotta, S., Tonini, M., Vakil, N., \& Bianchi Porro, G. (2008). Systematic review: gastrooesophageal reflux disease and dental lesions. Alimentary Pharmacology \& Therapeutics, 27(12), 1179-1186.

Pandolfino, J., Bianchi, L., Lee, T., Hirano, 1., \& Kahrilas, P. (2004). Esophagogastric junction morphology predicts susceptibility to exercise-induced reflux. Am J Gastroenterol. 2004;99:1430-1436. The American Journal of Gastroenterology, 99(8), 1430-1436.

Paryag, A., \& Rafeek, R. (2014). Dental Erosion and Medical Conditions: An Overview of Aetiology, Diagnosis and Management. The West Indian Med Journal, 63(5), [Epub ahead of print].

Pedersen, A., Bardow, A., Jensen, S., \& Nauntofte, B. (2002). Saliva and gastrointestinal functions of taste, mastication, swallowing and digestion. Oral Diseases, 8(3), 117-129.

Pindborg, J. (1970). Pathology of the Hard Dental Tissues. Philadelphia, PA, USA: Saunders.

Postma, G. (2000). Ambulatory pH monitoring methodology. The Annals of Otology, Rhinology, and Laryngology, 184(10), 4.

Postma, G., Belafsky, P., Aviv, J., \& Koufman, J. (2002). Laryngopharyngeal reflux testing. Ear, Nose and Throat Journal, 81(9), 14-18.

Postma, G., Johnson, L., \& Koufman, J. (2002). Treatment of laryngopharyngeal reflux. Ear, Nose, and Throat Journal, 81(9), 24-26. 
Postma, G., Tomek, M., Belafsky, P., \& Koufman, J. (2001). Esophageal motor function in laryngopharyngeal reflux is superior to that in classic gastroesophageal reflux disease. The Annals of Otology, Rhinolology, and Laryngology, 110(12), 1114-1116.

Prasad, G., Bansal, A., Sharma, A., \& Wang, K. (2010). Predictors of progression in barrett's esophagus: current knowledge and future directions. The American Journal of Gastroenterology, 105(7), 1490-1502.

Prestes, L., Souza, B., Comar, L., Salomão, P., Rios, D., \& Magalhães, A. (2013). In situ effect of chewing gum containing CPP-ACP on the mineral precipitation of eroded bovine enamel-a surface hardness analysis. Journal of Dentistry, 41(8), 747-751.

Rabine, J., \& Nostrant, T. (2009). Oral manifestations of gastrointestinal diseases. In T. Yamada, D. Alpers, A. Kalloo, N. Kaplowitz, C. Owyang, \& P. D, Atlas of Gastroenterology (pp. 839-845). Oxford, United Kingdom: Blackwell Publishing.

Ranjitkar S, K. J. (2012). Gastroesophageal reflux disease and tooth erosion. International Journal of Dentistry, 2012:479850. doi: 10.1155/2012/479850. Epub 2011 Dec 12.

Ravi, N., Stuart, R., Byrne, P., \& Reynolds, J. (2005). Effect of physical exercise on esophageal motility in patients with esophageal disease. Diseases of the Esophagus, 18(6), 374-377.

Ravi, N., Stuart, R., Byrne, P., \& Reynolds, J. (2005). Effect of physical exercise on esophageafEffect of physical exercise on esophageal motility in patients with esophageal disease. Distal Esophagus, 18(6), 374-377.

Richter JE, W. W., Blackwell, J., Nelson III, J., Castell, J., \& Castell, D. (1987). Esophageal manometry in 95 healthy adult volunteers. Variability of pressures with age and frequency of "abnormal" contractions. Digestive Diseases and Sciences, 32(6), 583-592.

Rubenstein, J., \& Chen, J. (2014). Epidemiology of gastroesophageal reflux disease. Gastroenterology Clinics of North America, 43(1), 1-14.

Rustgi, A., \& Sun, W. (2009). Esophageal Neoplasms. In T. Yamada, D. Alpers, A. Kalloo, N. Kaplowitz, C. Owyang, \& D. Powell, Atlas of Gastroenterology (Vol. 4th Edition, pp. 196204). Oxford, United Kingdom: Blackwell Publishing.

Samuels, T., \& Johnston, N. (2009). Pepsin as a causal agent of inflammation during nonacidic reflux. Otolaryngology-Head and Neck Surgery, 141(5), 559-563.

Sandler, R., Everhart, J., Donowitz, M., Adam, s. E., Cronin, K., Goodman, C., et al. (2002). The burden of selected digestive diseases in the United States. Gastroenterology, 122, 15001511.

Schroeder, P. L. (1995). Dental erosion and acid reflux disease. Annals of internal medicine, $122(11), 809-815$. 
Scott, M., \& Gelhot, A. (1999). Gastroesophageal reflux disease: diagnosis and management. American Family Physician, 59(5), 1161-1169, 1199.

Shaker, R., Castell, D., Schoenfeld, P., \& Spechler, S. (2003). Nighttime heartburn is an underappreciated clinical problem that impacts sleep and daytime function: the results of a Gallup survey conducted on behalf of the American Gastroenterological Associat. The American Journal of Gastroenterology, 98(7), 1487-1493.

Silva, M., Damante, J., Stipp, A., Tolentino, M., Carlotto, P., \& Fleury, R. (2001). Gastroesophageal reflux disease: New oral findings. Oral Surgery, Oral Medicine, Oral Pathology, Oral Radiology and Endodontics, 91(3), 301-310.

Sivasithamparam, K., Harbrow, D., Vinczer, E., \& Young, W. (2003). Endodontic sequelae of dental erosion. Australian Dental Journal, 48(2), 97-101.

Smith, J., Gavey, C., Nwokolo, C., \& Pounder, R. (1990). Tolerance during 8 days of high-dose H2blockade: placebo-controlled studies of 24-hour acidity and gastrin. Alimentary Pharmacology \& Therapeutics, 4(1), 47-63.

Smoak, B., \& Koufman, J. (2001). Effects of gum chewing on pharyngeal and esophageal pH. The Annals of Otology, Rhinology, and Laryngology, 110(2), 1117-1119.

Sonnenberg, A., \& El-Serag, H. (1999). Clinical epidemiology and natural history of gastroesophageal reflux disease. The Yale Journal of Bioogy and Medicine , 72(2-3), 8192.

Sonnenberg, A., Inadomi, J., \& Becker, L. (1999). Economic analysis of step-wise treatment of gastro-oesophageal reflux disease. Alimentary Pharmacology \& Therapeutics, 13(8), 1003-1013.

Søvik, J., Skudutyte-Rysstad, R., Tveit, A., Sandvik, L., \& Mulic, A. (2015). Sour Sweets and Acidic Beverage Consumption Are Risk Indicators for Dental Erosion. Caries Research, 49(3), 243-250.

Spencer, J. (1969). Prolonged pH recording in the study of gastroesophageal reflux. British Journal of Surgery, 56, 912-914.

Sturm, R. (2002). The effects of obesity, smoking and drinking on medical problems and costs. Health Affairs, 21(2), 245-253.

Sweis, R, Fox, M., Anggiansah, A., \& Wong, T. (2011). Prolonged, wireless pH-studies have a high diagnostic yield in patients with reflux symptoms and negative $24 \mathrm{~h}$ catheter-based $\mathrm{pH}$ studies. Neurogastroenterology and Motility, 23(5), 419-442. 
Sweis, R., Fox, M., Anggiansah, A., \& Wong, T. (2011). Prolonged, wireless pH-studies have a high diagnostic yield in patients with reflux symptoms and negative $24 \mathrm{~h}$ catheter-based $\mathrm{pH}$ studies . Neurogastroenterology and Motility, 23(5), 419-426.

Tay, F., \& Pashley, D. (2004). Resin bonding to cervical sclerotic dentin: a review. Journal of Dentistry, 32(3), 173-196.

Thie, N., Kato, T., Bader, G., Montplaisir, J., \& Lavigne, G. (2002). The significance of saliva during sleep and the relevance of oromotor movements. Sleep Medicine Reviews, 6(3), 213-227.

Tseng, D., Rizvi, A., Fennerty, M., Jobe, B., Diggs, B., Sheppard, B., et al. (2005). Forty-eight-hour $\mathrm{pH}$ monitoring increases sensitivity in detecting abnormal esophageal acid exposure. Journal of Gastrointestinal Surgery, 9(8), 1043-1051.

Valitova, E., Bayrakçı, B., \& Bor, S. (2013). The effect of the speed of eating on acid reflux and symptoms of patients with gastroesophageal reflux disease. The Turkish Journal of Gastroenterolgoy, 24(5), 379-381.

Wang, F., Tu, M., Chuang, H., Yu, H., Cheng, L., \& Hsu, P. (2010). Erosive esophagitis in asymptomatic subjects: risk factors. Digestive Diseases and Sciences, 55(5), 1320-1324.

Ward, P., \& Hanson, D. (1988). Reflux as an etiological factor of carcinoma of the laryngopharynx. The Laryngoscope, 98(11), 1195-1199.

Waring, J. (1999). Postfundoplication complications. Prevention and management. Gastroenterology, 28(4), 1007-1019.

Wenner, J., Johnsson, F., Johansson, J., \& Oberg, S. (2007). Wireless esophageal pH monitoring is better tolerated than the catheter-based technique: results from a randomized crossover trial. The American Journal of Gastroenterology, 102(2), 239-245.

Wilder-Smith, C., Ernst, T., Gennoni, M., Zeyen, B., Halter, F., \& Merki, H. (1990). Tolerance to oral H2-receptor antagonists. Digestive Diseases and Sciences, 35(8), 976-983.

Wilson, J., \& Heading, R. (1993). The Proximal Sphincters. In W. D. Kumar D, \& W. D. Kumar D (Ed.), An Illustrated Guide to Gastrointestinal Motility (Second ed., pp. 357-372). London: Churchhill-Livingstone.

Yap, A., Lim, C., \& Neo, J. (1995). Marginal sealing ability of three cervical restorative systems. Quintessence International, 26(11), 817-820. 